\title{
City of Long Beach v. Bozek: An Absolute Right to Sue the Government?
}

In City of Long Beach v. Bozek, ${ }^{1}$ the California Supreme Court held that the government may not bring a malicious prosecution action against a private imdividual for suing the government unsuccessfully. The decision is important because it announced that an individual's constitutional right to petition for redress of grievances affords an absolute privilege to sue the government, no inatter how false or inalicious the claim. The court analogized to the law of defaination, under which courts have safeguarded freedoin of speech by barring governmental entities from bringing defamation actions against individuals who make statements critical of government. Governmental malicious prosecution suits, the court ruled, would have a similar chilling effect on the airing of legitimate grievances against the government. The court thus held inalicious prosecution suits by the government to be impermissible.

On January 10, 1983, the United States Supreine Court vacated and remanded the decision in Bozek for a determination of whether the holding relied upon United States constitutional grounds, Califorina state constitutional grounds, or both. ${ }^{2}$ The California Supreme Court responded on April 25, 1983, holding that its prior decision rested on both the first amendment to the United States Constitution and article I, section 3 of the California Constitution. ${ }^{3}$ Accordingly, it found an imdependent and adequate state ground for the decision and remstated its earlier opinion without modification. ${ }^{4}$ This Note argues that on either ground the court's decision constituted an imprudent and uumecessary expansion of a constitutional guarantee. The court's concerns

1. 31 Cal. 3d 527, 645 P.2d 137, 183 Cal. Rptr. 86 (1982), vacated and remanded, $103 \mathrm{~S}$. Ct. 712 (1983).

2. 103 S. Ct. 712 (1983). The remand was based on the doctrine of "independent and adequate state grounds." According to this doctrine, the United States Supreme Court lacks jurisdiction to review state decisions if they rested, at least in part, on state constitutional grounds. See Minnesota v. National Tea Co., 309 U.S. 551 (1940). The Supreme Court's grant of certiorari suggests that the Court was imterested in the case and might have reviewed it if the California Supreme Court had determined on remand that the decision relied solely on the federal Constitution. Had the case returned to the United States Supreme Court on federal grounds, this Note would have argued that the decision of the California Supreme Court should be reversed. See infra Section A of Part III.

3. 34 Cal. 3d 727, 661 P.2d 1072, 190 Cal. Rptr. 918 (1983).

4. Id. at 728,661 P.2d at 1073, 190 Cal. Rptr. at 919. 
could have been better met by imposing a higher standard of proof on governmental plaintiffs in malicious prosecution suits.

Part I of this Note outlines the facts of the Bozek case and reviews the California Supreme Court's inajority and dissenting opinions. Part II sets forth the legal background of the first amendinent right to petition, the California constitutional right to petition, and the common law tort of mahicious prosecution. Part III presents an analysis of the Bozek court's decision in hight of federal and California state precedent. Part IV suggests that the imposition of a burden of proof on governmental plaintiffs comparable to the "actual mahice" standard in defaination law would have achieved a better balance between an individual's right to petition the government through litigation and the government's legitimate interest in avoiding the needless waste of time and inoney spent in defending patently frivolous lawsuits.

\section{I \\ The CAse}

\section{A. The Facts}

Richard Bozek filed a suit agamst the city of Long Beach and two of its police officers, ${ }^{5}$ alleging false arrest, false imprisonment, assault, battery, and neghigent hiring. ${ }^{6}$ A jury held for the city and police officers, and they in turn sued Bozek for malicious prosecution. The city and police officers alleged that Bozek had instituted the prior action against them without probable cause and with knowledgc that the allegations in his complaint were false. ${ }^{7}$

The trial court sustained Bozek's demurrer without leave to ainend agamst the city of Long Beach on the ground that inunicipalities should not be permitted to sue private individuals for malicious prosecution. The appellate court reversed, holding that the right to petition is qualified, not absolute, and that it does not protect the bringing of lawsuits without probable cause and witl inalice. ${ }^{8}$ The California Supreine Court upheld the trial court's ruling.

\section{B. The Opinions}

In an opimion written by Justice Mosk, the majority ${ }^{9}$ ruled that the

5. The supreme court's decision applied only to the city; the police officers were free to pursue private malicious prosecution actions. Id. at $538 \mathrm{n} .9,645$ P.2d at $143 \mathrm{n} .9,183 \mathrm{Cal}$. Rptr. at 92 n.9.

6. Id. at $530,645 \mathrm{P} .2 \mathrm{~d}$ at $138,183 \mathrm{Cal}$. Rptr. at 87 .

7. Id.

8. 118 Cal. App. 3d 847, 850, 173 Cal. Rptr. 611, 612 (1981), officially depublished pursuant to CAL. CT. R. 976(d).

9. Justice Mosk was jomed by Chief Justice Bird and Justices Newman and Broussard. 
right to sue the government is absolutely privileged. It found that existing state statutory remedies ${ }^{10}$ were sufficient to protect the imterests of governmental entities seeking compensation for expenses imcurred in defending agamst unwarranted lawsuits. The majority felt that the amount of money expended in defending malicious prosecution actions is significantly greater than that imvolved in defendimg statutory claims for costs. These added expenses, as well as the fear of being sued for malicious prosecution, would inhibit those with legitimate grievances from bringing suit agamst the government.

In reaching this conclusion, the majority opinion began by considering the public policy concerns favoring suits by individuals for the tort of malicious prosecution. The court identified three major factors justifying compensation for inalicious prosccution: (1) psychological harm to a party who is maliciously prosecuted; (2) expenses incurred in defending the mahcious action; and (3) harm to the efficient administration of justice. ${ }^{11}$ The court reasoned that only the latter two factors, expense and efficient administration of justice, are imphicated when a nonindividual, such as a corporation or the government, is the subject of a maliciously prosecuted suit. The court decided that these two factors alone are sufficient to support a malicious prosecution action; psychological harm is not an essential element. The court therefore concluded that nonindividuals should generally be permitted to bring malicious prosecution suits. This allows plaimtiffs to recover court costs and satisfies the social goal of discouraging frivolous legal claims. ${ }^{12}$

Against the background of these common law tort interests, the Bozek majority focused on the constitutional question of whether governmental entities should nevertheless be barred from sumg for mahcious prosecution because of the potential chilling effect such actions would have on the right to petition. The court considered the scope of the right to petition by examining a line of United States Supreme Court cases mterpreting that right in the context of antitrust law. ${ }^{13}$ These cases, the inajority stated, made it clear that the first amendment

10. Cal. Crv. Proc. Code $\S 128.5$ (West 1982); id. $\$ 1021.7$ (West Supp. 1983). The statutes provide, in relevant part:

§ 128.5(a) Every trial court shall have the power to order a party or the party's attorney, or both, to pay any reasonable expenses, including attorney's fees, incurred by another party as a result of tactics or actions not based on good faith which are frivolous or which cause unnecessary delay.

$\$ 1021.7$ In any action for damages arising out of the performance of a peace officer's duties, brought against a peace officer . . . or against a public entity employimg a peace officer . . the court may, in its discretion, award reasonable attorney's fees to the defendant or defendants as part of the costs, upon a finding by the court that the action was not filed or maintained in good faith and with reasonable cause.

11. $31 \mathrm{Cal}$. 3d at 531, 645 P.2d at 138-39, 183 Cal. Rptr. at 87-88.

12. Id.

13. Eastern R.R. Presidents Conference v. Noerr Motor Freight, Inc., 365 U.S. 127 (1961); 
right to petition protects attempts to obtain a redress of grievances froin all three branches of government regardless of the petitioner's motive. ${ }^{14}$ The court also cited several lower court decisions ${ }^{15}$ outside the area of antitrust ${ }^{16}$ that refused to impose civil liability for conduct deemed to be an exercise of the right to petition. ${ }^{17}$

Having determined that the right to petition is constitutionally protected, and mcludes filing suit agamst a governmental entity, the court next analyzed the degree of protection to be accorded the exercise of the right. The only other case to have addressed the issue of whether a governmental entity may bring a malicious prosecution action was Board of Education of Miami Trace Local School District v. Marting, ${ }^{18}$ in which an Ohio court held that a school board nay not maintain an action for malicious prosecution against a taxpayer who had brought an unsuccessful suit agamst the school district. The majority in Bozek found most apt the Marting court's analogy to the law of defaination. ${ }^{19}$ Under the first amendment right of free speech, criticism of the government is afforded an absolute privilege. Governmental entities are thus precluded from bringing suit for defamation against those who criticize the government im any forin; the potential chilling effect such suits would otherwise have upon legitimate criticism of government and its practices overrides the government's interest in suing. ${ }^{20}$

The majority in Bozek was concerned that permitting governmental entities to sue for malicious prosecution could generate a similar chilling effect. Thus, it considered the existence of statutory remedies that enable governmental entities to recover the costs of defending against frivolous lawsuits. ${ }^{21}$ The court concluded that the potential chilling effect upon the right to petition, together with the availability of alternative statutory remedies, precluded the government from bringing suit for malicious prosecution.

In dissent, Justice Kaus ${ }^{22}$ argued that the majority opimion suf-

UMW v. Pennington, 381 U.S. 657 (1965); California Motor Transp. v. Trucking Unlimited, 404 U.S. 508 (1972).

14. 31 Cal. $3 d$ at $532-33,645$ P.2d at 139-40, 183 Cal. Rptr. at 88-89.

15. Id. at 533, 645 P.2d at 140,183 Cal. Rptr. at 89 . In addition, the court noted a line of Supreme Court cases which held that access to the courts is protected under the first amendment rights of petition and assembly. See infra note 32 .

16. The Bozek court noted that these cases analogized to the Noerr-Pennington cases. 31 Cal. 3d at 533, 645 P.2d at 140, 183 Cal. Rptr. at 89.

17. See, e.g., Missouri v. National Org. for Women, 620 F.2d 1301 (8th Cir. 1980) (convention boycott of states that had not ratifed the Equal Rights Amendment protected by first amendment right to petition).

18. 7 Ohio Misc. 64 (C.P. 1966).

19. 31 Cal. $3 d$ at 536,645 P.2d at $141-42,183$ Cal. Rptr. at 91.

20. Id. at 534-35, 645 P.2d at 141, 183 Cal. Rptr. at 90.

21. Id. at 537-38, 645 P.2d at 142-43, 183 Cal. Rptr. at $91-92$.

22. Justice Kaus was joined by Justice Richardson. 
fered from two fatal errors in logic. First, Kaus argued, the cases upon which the majority relied for an imterpretation of the scope of the right to petition hold that the right protects an individual's right to bring suit agamst the government. Additionally, they hold that the right to petition mcludes the right of a private individual to bring suit agamst another private individual as a means of petitioning the government for a redress of grievances caused by the latter individual. ${ }^{23}$ If the right to petition is an unqualified right, as the inajority asserted, then all mahcious prosecution suits, whether filed by a governmental entity, or by a private individual through the government's judicial system, would necessarily be unconstitutional abridgments of the right to petition. ${ }^{24}$

Kaus also argued that the very statutes the majority deferred to as an alternative to actions for malicious prosecution contradict the majority's assertion that there is an absolute privilege to sue the governinent. If there were truly an absolute privilege to sue the government, it would follow that an individual who knowingly filed a false claim against the government constitutionally could never have any penalty imposed upon him, includimg a statutory award of attorneys' fees. ${ }^{25}$

\section{II \\ BACKGROUND LAW \\ A. The Right to Petition}

The right to petition the government for a redress of grievances, as embodied in the Umited States ${ }^{26}$ and California ${ }^{27}$ Constitutions, is a basic right afforded all citizens. ${ }^{28}$ The right to petition was placed in the first amendment at the same time as the rights of freedom of speech and of the press. ${ }^{29}$ The California Constitution links the right to petition with rights of assembly and instructing representatives, but these rights were mcluded in the constitutional Declaration of Rights along

23. $31 \mathrm{Cal}$. 3d at 539-40, 645 P.2d at $144,183 \mathrm{Cal}$. Rptr. at 93.

24. Id. at 540,645 P.2d at 144, 183 Cal. Rptr. at 93.

25. Id. at 540, 645 P.2d at $144-45,183$ Cal. Rptr. at 94.

26. "Congress shall make no law . . abridging the freedom of speech, or of the press; or the right of the people peaceably to assemble, and to petition the Government for a redress of grievances." U.S. CoNST. amend. I.

27. "The people have the right to instruct their representatives, petition government for redress of grievances, and assemble freely to consult for the common good." CAL. CoNSr. art. 1, § 3 .

28. United States v. Cruikshank, 92 U.S. 542, 552 (1875); Robims v. Pruneyard Shopping Center, 23 Cal. 3d 899, 907-08, 592 P.2d 341, 345, 153 Cal. Rptr. 854, 858 (1979) (citing Cruikshank and noting that the right to petition "is vital to a basic process in the state's constitutional scheme-direct initiation of change by the citizenry through initiative, referenduın, and recall"), affd, 447 U.S. 74 (1980).

29. The first amendment was adopted in its entirety on December 15, 1791, following ratifcation by three-fourths of the states. See H. LEE, THE STORY OF THE CONSTitution 102 (1932). 
with rights of free speech and press. ${ }^{30}$ The right to petition has not been examined as carefully as have these accompanying rights. Most discussions of the right to petition have instead been associated with discussions of other constitutional issues. ${ }^{31}$

The most significant elaboration by the United States Supreme Court of the right to petition has developed in the area of antitrust law. ${ }^{32}$ The Court has held that the right to petition protects attempts to obtain a redress of grievances fronl all three branches of government. In Eastern Railroad Presidents Conference v. Noerr Motor Freight, ${ }^{33}$ the Supreme Court held that the first anendment right to petition protected a publicity campaign aimed at influencing the legislature, even if the campaign was undertaken to promote legislation that would inhibit competition from the trucking industry. Similarly, in United Mine Workers v. Pennington, ${ }^{34}$ attempts to influence members of the executive branch were protected by the right to petition. Finally, in California Motor Transport $v$. Trucking Unlimited ${ }^{35}$ efforts to obtain redress of grievances through administrative or judicial proceedings were also judged to be privileged. As the Court stated in Noerr, the exercise of the right to petition "cannot properly be made to depend upon [the petitioner's] intent in doing so." ${ }^{36}$ After these cases, the concept that the right to petition immunizes attempts to influence the legislative, executive, and judicial branches has come to be known as the Noerr-Pennington doctrine.

The Supreme Court has recognized a significant limitation on the Noerr-Pennington doctrine, known as the "shanl" exception. ${ }^{37}$ Under this exception, a petitioner who attempts to influence a given branch of government as a direct effort to interfere with a competitor's busimess is not protected by the first amendinent right to petition and may be sub-

30. Cal. Const. art. I, $\$ 2$ (1974, amended 1980); Cal. Const. art. I, § 3.

31. The Supreme Court has stated specifically that the freedoms of speech and of the press are "cognate" to and "inseparable" from the rights to peaceably asseinble and to petition. Thomas v. Collins, 323 U.S. 516, 530 (1945). The Bozek court recognized the close relationship: "The right of petition, like the other rights contamed in the First Amendinent and in the Califorma constitutional Declaration of Rights, is accorded 'a paramount and preferred place in our democratic systenn." 31 Cal. 3d at 532, 645 P.2d at 139, 183 Cal. Rptr. at 88 (citation omitted).

32. The Supreme Court has considered the right to petition, though not as carefully, in other contexts. The leading case is NAACP v. Button, 371 U.S. 415 (1963), where the Court found first amendinent protection of the right to associate with others for the purpose of providing legal assistance to members of a minority group. See also United Transp. Union v. State Bar, 401 U.S. 576 (197I); UMW v. Illinois State Bar Ass'n, 389 U.S. 217 (1967); Brotherhood of R.R. Trainmen v. Virginia ex rel. Virgimia State Bar, 377 U.S. 1 (1964).
33. 365 U.S. 127, 136-37 (1961).
34. 381 U.S. 657,670 (1965).
35. 404 U.S. $508,510-11$ (1972).
36. 365 U.S. at 139.
37. Id. at 144. 
ject to antitrust liability. ${ }^{38}$ Courts have used this sham exception to determine whether certain ostensible exercises of the right to petition are indeed constitutionally protected. ${ }^{39}$

\section{B. Malicious Prosecution}

Malicious prosecution is a common law action designed to protect mdividuals from unjustified litigation. ${ }^{40}$ Malicious prosecution originally referred only to the wrongful institution of criminal proceedimgs, but judicial decisions gradually expanded the scope of the tort to include unwarranted civil proceedimgs. ${ }^{41}$

California has long recognized a cause of action for civil malicious prosecution. ${ }^{42}$ Such inalicious prosecution constitutes an improper use of the judicial system. ${ }^{43}$ As the California Supreme Court stated in Bozek, "[M]alicious commenceinent of a civil proceeding is actionable because it harms the mdividual against whom the claim is made, and also because it threatens the efficient administration of justice." ${ }_{44}$ The individual is harnied in two respects: He suffers psychological injury

38. Id

39. See, e.g., United States v. Otter Tail Power Co., 360 F. Supp. 451 (D. Minn. 1973) (repetitive use of litigation constituted a sham designed principally to preserve monopoly), affd mem. , 417 U.S. 901 (1974); Clipper Exxpress v. Rocky Mountain Motor Tariff Burcau, Inc., 674 F.2d $1252,1262-69$ (9th Cir. 1982) (it is a jury question whether protests filed with ICC constituted a sham); Forro Precision, Inc. v. IBM, 673 F.2d 1045, 1060 (9th Cir. 1982) (request for help from police department not a sliam). Commentators liave discussed extensively the sham exception and its effect on the right to petition. See R. BORK, THe ANTITrust Paradox: A Policy at War with ITSElF ch. 18 (1978); L. SUllivan, HaNdBOOK OF the LaW OF ANTITRUST $\$ 238$, at 742 (1977); Balmer, Sham Litigation and the Antitrust Laws, 29 BufFalo L. Rev. 39 (1980); Fischel, Antitrust Liability for Attempts to Infiuence Government Action: The Basis and Limits of the NoerrPennington Doctrine, 45 U. CHl. L. REv. 80, 104-10 (1977); Kaler, The Sham Exception to the Noerr-Pennington Antitrust Immunity: Its Potential for Minimizing Anticompetitive Abuse of the Administrative Regulatory Process, 12 U. ToL. L. REV. 63 (1980); Note, Limiting the Antitrust Immunity for Concerted Attempts to Infiuence Courts and Adjudicatory Agencies: Analogies to Mallicious Prosecution and Abuse of Process, 86 HARv. L. REv. 715, 723-26 (1973).

40. W. Prosser, HANDBOOK OF THE LAW OF TORTS $\$ 119$, at 834 (4th ed. 1971). The imposition of civil liability las been described as "the centerpiece of the present American system for deterring groundless litigation." Note, Groundless Litigation and the Malicious Proseeution Debate: A Historical Analysis, 88 YALE L.J. 1218, 1218 (1979).

41. See Comment, Malicious Prosecution-Recovery for Defamatory Pleadings Denied, 5 StaN. L. Rev. 151, 151 n.1 (1952). See generally W. ProsSER, supra note 40, § 120, at 850-56; 4 B. WITKIN, SUMMARY OF CALIFORNIA LAW Torts $\$ \S 255-261$ (8th ed. 1974).

42. Grant v. Moore, 29 Cal. 644 (1866).

43. See Bertero v. National Gen. Corp., 13 Cal. 3d 43, 51, 529 P.2d 608, 614, 118 Cal. Rptr. 184,190 (1974) ("The judicial process is adversely affected by a maliciously prosecuted cause not only by the clogging of already overcrowded dockets, but by the unscrupulous use of the courts by individuals :. . . as instruments with which to maliciously injure their fellow men." ") (quoting Teesdale v. Liebschwager, 42 S.D. 323, 325, 174 N.W. 620, 621 (1919)).

44. $31 \mathrm{Cal} .3 \mathrm{~d}$ at 531,645 P.2d at 138, $183 \mathrm{Cal}$. Rptr. at 87 (quoting Bertero, $13 \mathrm{Cal} .3 \mathrm{~d}$ at 50 , 529 P.2d at 614, 118 Cal. Rptr. at 190). The Bozek court made clear that its reference to an individual did not mean that only an individual may sue for malicious prosecution. See supra text accompanying notes 11-12. 
as a result of being subjected to a suit brought out of ill will, and he is forced to bear the legal expenses of defending against a frivolous claim. These harms combine with the negative impacts on the administration of justice to justify suits for inahious prosecution.

The majority im Bozek outlined the traditional elements of a civil cause of action for malicious prosecution: (1) the defendant in the unalicious prosecution action previously instituted proceedings against the plaintiff that were terminated in the plaintiff's favor; (2) the defendant lacked probable cause to bring the prior proceedimgs; and (3) the defendant brouglit the prior action witl inalice. ${ }^{45}$ A successful action for malicious prosecution entitles the plaintiff to compensation for the harm le suffered as a result of the prior action, including any reasonable costs he mcurred im defending that action. ${ }^{46}$ The costs of pursumg the inalicious prosecution action, lowever, are not normally recoverable. ${ }^{47}$

\section{III \\ ANALYSIS \\ A. The Decision Considered in Light of Federal Precedent}

\section{Limitations on the Right to Petition}

The Califormia Supreme Court determined on remand that the decision in Bozek rested partly on federal constitutional grounds. The conclusion that there is an absolute privilege to sue the government, lowever, is an unwarranted and unprecedented expansion of first amendment protections. Since the early nineteenth century, cases considering the scope of the right to petition ${ }^{48}$ have held that where mahce can be demonstrated, there may be liability for the bringing of an unwarranted lawsuit. ${ }^{49}$

45. $31 \mathrm{Cal}$. 3d at 530-31, 645 P.2d at 138, $183 \mathrm{Cal}$. Rptr. at 87 . Various purposes that would constitute malice are identified in Albertson v. Raboff, 46 Cal. 2d 375, 383, 295 P.2d 405, 410-11 (1956).

46. W. Prosser, supra note $40, \S 119$, at 850 .

47. Id; see also Bertero, $13 \mathrm{Cal}$. 3d at 59, $529 \mathrm{P.2d}$ at $620,118 \mathrm{Cal}$. Rptr. at 196 (in addition to compensation for injury to reputation and for emotional distress, "the measure of conpensatory damages for the inalicious prosecution of a civil action imcludes attorney fees and court costs for defending the prior action.") (emphasis added).

48. Though decided in state rather than federal courts, these cases do not indicate they were offering a umque interpretation of the right to petition under their state constitution. Accordingly, the state cases provide valid interpretations of the federal constitutional right to petition.

49. In Thorn v. Blanchard, 5 Johns. 508 (N.Y. 1809), for example, an individual had petitioned for the removal of a public official, alleging malfeasance in office. The official sued the individual for libel. The New York Court for Correction of Errors reversed the initial verdict for the plaintiff, holding that only a showing of malice would warrant liability. Id. at 526-32. See Vanderzee v. M'Gregor, 12 Wend. 545 (N.Y. Sup. Ct. 1834) (explaining the Thorn rule). Other courts similarly permitted recovery on a showing of inalice. See, e.g., Howard v. Thompson, 21 
More recently, the United States Suprene Court has echoed this sentiment; it is only legitimate exercises that are protected by the first amendnrent right to petition. In the Noerr-Pennington line of cases, in which the Suprenue Court provided the nost coniprehensive interpretation of the right, ${ }^{50}$ the shan exception placed a significant limitation upon the exercise of the right to petition. ${ }^{51}$ The California court in Bozek, though it relied upon the Noerr-Pennington cases for an authoritative interpretation of the right to petition, failed to consider this significant exception.

In United States v. Rock Royal Co-operative, Inc., ${ }^{52}$ a case relied on in Noerr to fornulate the shanl exception, the Supreine Court held that the existence of a valid purpose was enough to invoke the privilege of the first anendnent right to petition. ${ }^{53}$ Where there is no valid purpose behind the exercise of the right, however, there is no constitutional protection. ${ }^{54}$ As one commentator put it, "construing the right to petition to protect deliberate misrepresentations and baseless claims not presented in good faith would devalue the first amendnient right to petition." 55

Outside the context of antitrust law, the Suprene Court has also implicitly affirmed the notion that it is only serious exercise of the right to petition that is protected. As Justice Bremian stated in $N A A C P$ v. Button," "[R]esort to the courts to seek vindication of constitutional rights is a different inatter front the oppressive, malicious, or avaricious use of the legal process for purely private gain." 57

Wend. 319 (N.Y. Sup. Ct. 1839) (charge made to Secretary of the Treasury against Inspector of Customs and Keeper of the Public Stores); Bodwell v. Osgood, 20 Mass. 379, 3 Pick. 408 (1825) (charge inade to local school committee against public school teacher); Gray v. Pentland, 2 Serg. \& Rawle 23 ( $\mathrm{Pa}$. 1815) (charge inade to government against prothonotary of common pleas court).

50. See supra notes $32-36$ and accoinpanying text.

51. See supra notes $37-39$ and accompanying text.

52. 307 U.S. 533 (1939).

53. The Court stated that if a milk pricing order and the act that authorized it "are otherwise valid," the actions of milk producers would not violate the antitrust laws, even if their purpose was to gain a monopoly. Id. at 560 .

54. California Motor Transp. v. Trucking Unlimited, 404 U.S. 508, 514-15 (1972). See Matossian v. Fahmie, 101 Cal. App. 3d 128, 161 Cal. Rptr. 532 (1980), cited in Bozek to support the conclusion that the right to petition limits suits for malicious prosecution. $31 \mathrm{Cal} .3 \mathrm{~d}$ at 533, 536 n.6, 645 P.2d at 140, 141 n.6, 183 Cal. Rptr. at 89, 91 n.6. Unlike Bozek, the defendants in Matossian had a specific statutory right to bring the petitions for which they were later sued. 101 Cal. App. 3d at 133, 137, 161 Cal. Rptr. at 534, 537. As the Matossion court observed, " [T] motive, even if mahicious, of defendants is unimportant if legal ground existed upon which to predicate' their protests." 101 Cal. App. 3d at 137, 161 Cal. Rptr. at 536 (emphasis added) (quoting Paskle v. Willians, 214 Cal. 482, 487, 6 P.2d 505, 507 (1931)).

55. Fischel, supra note 39, at 101. See also Balmer, supra note 39, at 60 ("Sham litigation, like intentional falsehoods, serves no first amendment interest that would rcquire constitutional protection.").

56. 371 U.S. 415 (1963).

57. Id at 443. Bozek was not seeking vimdication of any constitutional rights, but the right 
The inajority opinion in Bozek suggests that the very existence of the common law tort of malicious prosecution acts as a limit on the right to petition. ${ }^{58}$ The real question in Bozek, therefore, is whether the right to petition the government for a redress of grievances should be accorded greater protection when the harm was allegedly suffered at the hands of the government. ${ }^{59}$ The majority in Bozek felt that suits agamst the government were indeed a unique exercise of the right to petition and therefore should be specially protected, much as criticism of the government is a specially protected exercise of the right to free speech. The next section of this Note argues, however, that the majority's analogy to defamation law, under which governmental entities are precluded from bringing suit by the first amendment, is incorrectly drawn.

\section{Analogy to Defamation}

The majority in Bozek predicted that if governmental entities were permitted to sue for malicious prosecution, the specter of such actions would deter individuals with legitinate grievances against the government from pressing their claims. ${ }^{60}$ The inajority considered the right to petition parallel, and of comparable importance, to the right of free speech. It therefore analogized the malicious prosecution action in Bozek to the law of defamation, under which governmental entities are precluded from sumg for defamation in order to prevent a chilling effect on legitimate criticisms of the government. ${ }^{61}$ The majority's anal-

to petition is not limited to suits that are "bound up with political matters of acute social moment, as in Button . . . ." UMW v. Illinois State Bar Ass'n, 389 U.S. 217, 223 (1967).

58. Justice Kaus, in dissent, observed that the right to petition protects private lawsuits between individuals. If the majority leeld that the right to petition is absolute, then individual malicious prosecution suits would be just as unconstitutional as governmental malicious prosecutions suits, since both infringe on the right to petition. Therefore, the very fact that California recognizes the validity of individual malicious prosecution actions "belie[s] the majority's absolutist approach." 31 Cal. 3d at 540, 645 P.2d at 144, 183 Cal. Rptr. at 93-94. See supra text accompanying notes 22-24.

59. Kaus failed to recognize that the court did not hold that the right to petition is absolute. Instead, the court found that "the bringing of suits against the government is absolutely privileged ...." 31 Cal. 3d at 539, 645 P.2d at 143, 183 Cal. Rptr. at 93 (emphasis added).

60. Id. at 535, 645 P.2d at 141, 183 Cal. Rptr. at 90 ("If cities are permitted to bring malicious prosecution actions against those who have unsuccessfully sued them, the institntion of legitimate as well as baseless legal claims will be discouraged.").

61. This rule was adopted in California in City of Albany v. Meyer, 99 Cal. App. 651, 279 P. 213 (1929). The Bozek court expressed the policy behind the rule: "If the courts were to condone the imposition of civil sanctions . . . a severe chilling effect would result on the legitimate exercise of the right to express beliefs freely when those beliefs appear to be derogatory of the governing authorities." 31 Cal. 3d at 535, 645 P.2d at 141, 183 Cal. Rptr. at 90. See also Johnson City v. Cowles Communications, Inc., 477 S.W.2d 750, 754 (Tenn. 1972) ("It is difficult to imagine anything more destructive of democratic government than the power in the hands of a corrupt governmeut to stifle all opposition by free use of the public treasury to silence critics by suit."). 
ogy to defamation was, however, deficient. Important differences exist between the government's position as a plaintiff in malicious prosecution actions and defannation actions.

Both the common law actions of defannation and malicious prosecution rely heavily on the need to compensate individuals for the embarrassinent and emotional distress they have suffered. Where the defendant $\mathrm{m}$ a defaination or inalicious prosecution action is a governmental entity, the emotional distress justification cannot apply, as the government cannot suffer psychological harm. ${ }^{62}$ The absence of this justification weakens the need for the government to bring either type of action. The Bozek majority recognized, however, that the emotional distress justification was not essential for malicious prosecution actions when it mdicated that a nonmdividual other than the government might act as a plaintiff in a malicious prosecution action.

The analogy between defamation and malicious prosecution fails, however, to address adequately the substantial differences in financial harm suffered by governmental entities facing maliciously motivated litigation as opposed to those facing mere defamatory remarks. ${ }^{63}$ Litigation is expensive, and the inoney the government uses to defend against frivolous or malicious litigation must come from the public. The public's strong interest in avoiding the waste of public funds weighs heavily in favor of permitting the government, at least in some circumstances, to bring inalicious prosecution actions to recover its costs incurred in defending frivolous suits. The Bozek majority admitted that the government suffers harin from mahicious prosecutions, both in teruns of unnecessary expenses and imterference with the efficient administration of justice. ${ }^{64}$

The existence of defaination and inalicious prosecution actions presumably has a deterrent effect on those who would make slanderous and inalicious attacks on others. Where the subject of the attack is the government, however, it is extremely difficult to draw the line between just and unjust criticisin. Under either cause of action, the possibility exists that legitinate criticism will be deterred for fear of government retaliation im the forn of a defanation or inalicious prosecution suit.

62. See supra text accompanying notes 11-12.

63. Where defamatory remarks go beyond mere criticism, however, and reach the level of inciting violence, the Supreme Court has held that the constitutional right of free speech must yield to the need to protect the very structure of government. The Court therefore has upheld criminal penalties for speech that incites violence. Dennis v. United States, 341 U.S. 494 (1951) (upholding constitutionality of Smith Act, which proscribed advocating overthrow by force or violence of United States Government). But see Brandenburg v. Ohio, 395 U.S. 444 (1969) (limiting proscriptive power to advocacy directed to imciting or producing imminent lawless action and likely to imcite or produce such action). The limitations of Brandenburg do not change the government's ability to criminally pnnish certain types of speech.

64. 31 Cal. 3d at 538, 645 P.2d at 143, 183 Cal. Rptr. at 92. 
Government defamation suits and malicious prosecution actions, however, differ significantly in the extent to which they are likely to chill the exercise of important constitutional rights.

The majority in Bozek stated that the tort of malicious prosecution is easily alleged but difficult to prove. ${ }^{65}$ The court thus suggested that since malicious prosecution actions are easily brought, governmental entities might make use of the cause of action as a method of liarassing those who sued them, hence deterring legitimate actions against the government. In fact, lowever, the notion that inalicious prosecution actions are easy to allege but difficult to prove is better evidence for the opposite conclusion. Since the government unust be vigilant in controlling expenditures of public funds, the government will institute malicious prosecution suits only when it has strong evidentiary support for its claim. Thus, those with legitimate grievances lave little reason to fear. In a unalicious prosecution action the plaintiff may recover only the expenses he incurred in defending against the prior action. He may not recover the cost of pursuing the inalicious prosecution action itself. ${ }^{66}$ It stands to reason, therefore, that a governmental entity would not bring a suit for mahicious prosecution unless it could prove its allegations speedily, and unless the amount it stood to gam was significantly greater than the cost of pursuing the malicious prosecution action itself, that is, ouly in the inost extreme cases. If the government did otherwise it would only compound its loss.

In summary, government actions for malicious prosccution and defamation differ in two important respects: (1) in defending unwarranted lawsuits, governmental entities suffer tangible and measurable harın, unlike governmental entities subjected to unjust criticism, and (2) the chilling effect of government malicious prosecution actions is less than that of government defamation actions. Because the court in Bozek ignored these distinctions the majority was too quick to analogize between the two and enjoin governmental entities from suing for malicious prosecution. The analogy the inajority drew between malicious prosecution and defamation is somewhat apt, however - im both cases there remains the necessity to protect constitutional rights. To address this need, it will be argued ${ }^{67}$ that the court should have utilized a device borrowed from defamation law-imposition of a higher standard of proof on governmental plaintiffs than nongovernmental plaintiffs in malicious prosecution actions. First, however, it is necessary to examine the state constitutional grounds on which the majority relied in Bozek.

65. Id. at 535, $645 \mathrm{P} .2 \mathrm{~d}$ at $141,183 \mathrm{Cal}$. Rptr. at 90 .

66. See supra notes $46-47$ and accompanying text.

67. See infra notes $94-99$ and accompanying text. 


\section{B. California State Grounds for the Decision}

On remand, the California Supreme Court held that the decision in Bozek was based at least in part on state constitutional grounds. ${ }^{68}$ The court's conclusion that the California constitutional right to petition $^{69}$ affords an independent and adequate state ground suggests it is likely the decision rehied on an expansive reading of the Cahifornia Constitution, ${ }^{70}$ a right potentially broader than that granted by the United States Constitution. The United States Supreme Court has recognized that state courts may grant broader protection under their own constitutions than is provided by the federal Constitution. ${ }^{71}$ This is true even if the language declaring the right in a given state constitution is almost identical in wording to a corresponding section of the United States Constitution. ${ }^{72}$ In the past, the Cahfornia Supreme Court has interpreted state constitutional rights to provide broader protections than parallel rights enumerated by the federal Constitution, ${ }^{73}$

68. See supra text accompanying note 3 .

69. CAL. Const. art. I, § 3 , quoted at supra note 27.

70. This likelihood is increased given the impropriety of finding an absolute right to sue the government under the federal Constitution. See supra Section A of Part III.

71. Prune Yard Shopping Center v. Robins, 447 U.S. 74, 81 (1980) ("'The Court's interpretation does not] limit the authority of the State to exercise its police power or its sovereign right to adopt in its own Constitution individual liberties more expansive than those conferred by the Federal Constitution."). See also Brennan, State Constitutions and the Protection of Individual Rights, 90 HARV. L. Rev. 489, 498-502 (1977) (state courts have independently considered the merits of constitutional arguments and have declined to follow the United States Supreme Court where they found the opinions unconvincing, even where the state and federal constitutions are similarly or identically phrased); Developments in the Law-The Interpretation of State Constitu. tional Rights, 95 HARV. L. REv. 1324 (1982) (critique of the present and future role of state bills of rights).

72. The original language in the California Constitution differed from the first amendinent in that the California Constitution referred only to the right to petition the "Legislature." CAL. CoNST. art. I, \& 10 (1849, repealed 1974). In 1969, the California Constitution Revision Cominission evaluated this language and concluded that "the currently expressed purposes of Section 10 are too narrow and should be broadened at least to conform with the scope of the First Amendment . . . " California Const. Rev. Comm'n, ARTiCle I-DeClaration of Riohts-BackGROUND STUDY 3, at 31 (Oct. 1969). The suggestion was adopted; the final recommendation was that the section "be retained and broadened to permit the petition 'of government' in general rather than merely the 'Legislature'." 5 CALIFORNIA CONST. Rev. COMM'N, CALIForNIA Const. REv. COMM'N REPORT 23 (1971). The state constitution was thus amended in the Novenber 1974 general electiou. See Bozek, 31 Cal. 3d at 534 n.4, 645 P.2d at 140 n.4, 183 Cal. Rptr. at 89 n.4.

73. The courts's policy was stated recently in People v. Bustainante, $30 \mathrm{Cal} .3 \mathrm{~d} 88,634$ P.2d 927, 177 Cal. Rptr. 576 (1981):

[J]ust as the United States Supreme Court bears the ultimate judicial responsibility for determining matters of federal law, this court bears the ultimate judicial responsibility for resolving questions of state law, including the proper interpretation of provisions of the state Constitution. In fulfilling this difficult and grave respousibility, we cannot properly relegate our task to the judicial guardians of the federal Constitution, but instead must recognize our personal obhigation to exercise independent legal judgenent in ascertaining the meaning and application of state constitutional provisions.

1d. at 97, 634 P.2d at 932, 177 Cal. Rptr. at 581-82 (citations onitted) (quoting People v. Chavez, 26 Cal. 3d 334, 352, 605 P.2d 401, 412, 161 Cal. Rptr. 762, 773 (1980)). 
particularly in the area of criminal procedure. ${ }^{74}$ In Bozek, then, the California Supreme Court is not constramed by the fact that the federal Constitution inay not afford an absolute privilege to suits by individuals agamst governmental entities.

\section{The Internal Inconsistency of the Holding}

Even if Bozek rested upon state constitutional grounds, the holding suffers froin a fundainental internal inconsistency. On one hand, the court declares that suits against the government are protected by an absolute privilege. ${ }^{75}$ On the other hand, the court implicitly upholds the constitutionality of state statutes that limit that right by imposing civil and criminal penalties upon those who act in bad faith or file false claims against the government. ${ }^{76}$ Indeed, the inajority's rationale for its holding appears to rely on the availability to governmental entities of certain alternative statutory remedies. ${ }^{77}$ Presuunably then, the Bozek majority did not mean, as it said, ${ }^{78}$ that the right to bring suit against the government is absolutely privileged. Instead, it is likely that the majority meant to hold only that the California constitutional right to petition is sufficiently privileged to preclude the government from bringing mahicious prosecution suits, but not so privileged as to preclude alternative state statutory remedies. ${ }^{79}$

\section{The Inadequacy of the State Statutory Remedies}

The majority opinion in Bozek emphasizes that state statutory renedies available to the government are adequate to secure reimbursement for expenses incurred in defending against an unwarranted

74. See People v. Disbrow, 16 Cal. 3d 101, 545 P.2d 272, 127 Cal. Rptr. 360 (1976) (privilege against self-incrimination); People v. Brisendine, 13 Cal. 3d 528, 531 P.2d 1099, 119 Cal. Rptr. 315 (1975) (search and seizure clause); Curry v. Superior Court, 2 Cal. 3d 707, 470 P.2d 345, 87 Cal. Rptr. 361 (1970) (double jeopardy clause).

75. "[T] he bringing of suits against the government is absolutely privileged and cannot forn the basis for imposition of civil liability for malicious prosecution." 31 Cal. 3d at 539, 645 P.2d at 143, 183 Cal. Rptr. at 93.

76. Justice Kaus, in dissent, Inakes this point with regard to $\$ 72$ of the California Penal Code, which imposes criminal penalties for the filing of false claims with the government, $31 \mathrm{Cal}$. 3d at 540-41, 645 P.2d at 144-45, 183 Cal. Rptr. at 94, as well as to $\S 128.5$ of the California Civil Procedure Code, the general bad faith statute, 31 Cal. 3d at 541-42 \& n.3, 645 P.2d at 145-46 \& n.3, 183 Cal. Rptr. at 94-95 \& n.3, and to $\S 1021.7$ of the California Civil Procedure Code, the peace officer statute, 31 Cal. 3d at 542-43 \& n.5, 645 P.2d at $146 \&$ n.5, 183 Cal. Rptr. at 95 \& n.5.

77. "From a constitutional standpoint, an award of expenses upon a finding that inonetary sanctions are appropriate under the standards set out in the above statutes is a clearly preferable reinedy to an independent action for malicious prosecution . . . Bozek, $31 \mathrm{Cal}$. 3d at 538, 645 P.2d at 143, 183 Cal. Rptr. at 92 (emphasis added).

78. See supra note 75 .

79. The following argument assumes the court meant that the right to petition the government is not absolute, but instead is qualified to the extent that statutory remedies are available. 
lawsuit. $^{80}$ In particular, the majority referred to California Code of Civil Procedure sections 128.5 and 1021.7. The court failed to recognize, however, that the legislature enacted these statutes im order to supplement, not supplant, the government's option of bringing suit for makicious prosecution.

Section 128.5, for example, was never meant to permit recovery for a baseless lawsuit, which might spawn a mahcious prosecution action. Instead, the section was meant to apply only to frivolous or improper conduct within the confines of a legitimate lawsuit. The legislature enacted the section in direct response ${ }^{81}$ to a supreme court decision ${ }^{82} \mathrm{~m}$ volvimg attorney misbehavior in court. In addition, the legislative history mdicates that the statute should be applied only in such a situation. ${ }^{83}$ Based on this legislative history, the Bozek court misapphed the

80. 31 Cal. 3d at 530, 538, 645 P.2d at 138, 143, 183 Cal. Rptr. at 87, 92. The court's finding that the statutory remedies are adequate to provide a remedy to governmental entities ignores the fact that statutes may be repealed by the legislature that enacted them. If the statutory remedies relied on by the Bozek majority were repealed, it would remain uncertain whether the court's finding of an absolute privilege to sue the government could be based cntirely on the constitutional right to petition.

81. See Act of Sept. 24, 1981, ch. 762, \& 2, 1981 Cal. Legis. Serv. 2640, 2641 (West) ("It is the intent of this legislation to broaden the powers of trial courts to manage their calendars and provide for the expeditious processing of civil actions by authorizing monetary sanctions now not presently authorized by the imterpretation of the law in Baugess v. Paine . . . .").

82. Baugess v. Paine, 22 Cal. 3d 626, 586 P.2d 942, 150 Cal. Rptr. 461 (1978).

83. In Bozek, the California Supreme Court cited only the first part of $\S 128.5$, which allows sanctions for "tacties or actions not based on good faith which are frivolous or which cause uunecessary delay" and implicitly imterpreted the word "actions" to include lawsuits themselves. However, the bill as originally submitted in the state senate referred to "a frivolous motion filed solely to delay a trial or other proceeding" and the subsequent rewriting of the language appears to have been stylistic rather than substantive. See Cal. S. 947, 1981-82 Reg. Sess. (Mar. 26, 1981); id. (as amended Apr. 30, 1981); id. (as ainended May 28, 1981); id. (as amended Aug. 10, 1981) (codified at Cal. Crv. Proc. Code $\S 128.5$ (West 1982)).

Furthermore, the next sentence of the statute reads "[f]rivolous actions or delaying tactics include, but are not limited to, making or opposing motions without good faith." CAL. Civ. Proc. CODE § 128.5(a) (West 1982). Though the language states "include, but are not limited to," the legislature casily could have included the filing of malicious lawsuits in the definition had it wished to. Section 1021.7, Act of Sept. 29, 1981, ch. 980, § 1, 1981 Cal. Legis. Serv. 3665, 3665 (West), passed only 5 days after $\$ 128.5$, Act of Sept. 24, 1981, ch. 762, § 1, 1981 Cal. Legis. Serv. 2640,2640 (West), allows an award of attorneys' fees if "the action was not filed or maintained in good faith and with reasonable cause." CAL. CIv. Proc. CoDE \& 1021.7 (West Supp. 1983) (emphasis added). It is difficult to ascribe the same meaning to such different language when the two statutes were approved virtually at the same time by the same legislative body. The differences evidence an imtent to attach a different meaning to the two statutes with regard to the procedural aspects they reach.

The specific reference to Baugess in the legislative history, supra note 81 , suggests that the statute was dealing with a problem entirely unrelated to inahicious prosecution. The sanctions denied in Baugess were not songht because of a malicious prosecution, but because of attorney misconduct in conrt that resulted in a mistrial. See supra text accompanying notes 81-82. If $\$ 128.5$ does not apply to malicious prosecutions, the California Supreme Court seriously erred in deferring to that remedy as a substitute for malicious prosecution actions brought by a governmental entity. 
statute by indicating it encompasses inalicious prosecution actions.

Moreover, nothing in either section 128.5 or 1021.7 suggests that the statutes were meant to eliminate the government's right to sue for malicious prosecution. Where the legislature has intended a statutory remedy to provide an alternative, ratlier than a supplement, to the coininon law action of inalicious prosecution, the legislature has provided explicit language to that effect. ${ }^{84}$

Furthermore, the court in Bozek, by denying governmental entities the right to sue for inalicious prosecution, forecloses to the government all possibility of recovery in a certain class of legal proceedings. The statutes relied upon in Bozek provide only for an award of costs by "the trial court"8s or "the court." In a number of situations, sucl as with claims brought before a quasi-judicial administrative body, no court will be involved and the government therefore will be unable to recover. ${ }^{87}$

Cliarges of unfair labor practices committed by public school employers in California, for example, are heard before the Public Einployment Relations Board (PERB) ${ }^{88}$ The Board is einpowered to hold hearings on cliarges of unfair labor practices, to subpoena witnesses, to take the testimony or deposition of any person, and to issue subpoenas duces tecum requiring the production and examination of an employer's records, books, or papers. ${ }^{89}$ If the Board should determine that an unfair labor practice lias occurred, it may issue a cease and desist order and may require positive action, including the reinstateinent of employees witlı back pay. ${ }^{90}$

If a claim is filed agamst a local school district, the district could be required to participate in extensive investigation and hearing proce-

84. See CAL. CIv. PRoc. Code $§ 1038$ (West Supp. 1983). Section 1038 explicitly provides that if a motion for bad faith sanctions is made under the California Tort Claims Act, the moving party waives the right to sue for malicious prosecution. Id. at $\S 1038(c)$. Where such language is not present, we may presume the legislaturc intended the statutory remedies to be suppleinental to the common law remedy.

85. Id. \$ 128.5 , quoted at supra note 10.

86. Id. $\$ 1021.7$, quoted at supra note 10.

87. The statutes, by referring to "trial court" and "court," are clearly inapphicable to hearings before an administrative body. Section 128.5 was directed at a problem involving trial courts, see supra note 81 , and $\S 1021.7$ involves claims for damages against the police or their employers, which are brought only in the courts.

88. Council of Schrool Nurses v. Los Angeles Unified School Dist., 113 Cal. App. 3d 666, 169 Cal. Rptr. 893 (1980). The Public Employment Relations Board was created and given power under the Government Code to hear charges of unfair labor practices against public school employers. CAL. Gov'T CODE $\$ \S 3541,3541.3,3541.5$ (West 1980 \& Supp. 1983).

89. CAL. Gov't CODE $\$ 3541.3(\mathrm{~h})$ (West 1980).

90. Id $\S 3541.5(c)$. See Santa Morrica Community College Dist. v. Public Employınent Relations Bd., 112 Cal. App. 3d 684, 691, 169 Cal. Rptr. 460, 463-64 (1981) (upholding power of Board to order retroactive pay raise). 
dures, regardless of how frivolous and malicious the claim might be. The PERB might conceivably award costs to a party against whom a claim was maliciously brought, but this is far from certaim. Nothing im the legislative act authorizing the Board explicitly permits the awarding of such costs. ${ }^{91}$ Under California law prior to Bozek, the school district could have recovered its expenses by filing an action for malicious prosecution. ${ }^{92}$ The Bozek decision, lowever, precludes a governmental entity from suing for malicious prosecution, and, because the statutory remedies discussed in Bozek do not apply to an administrative hearing, the school district would be left without a remedy. ${ }^{93}$

\section{IV}

\section{A Proposed Solution}

In Bozek, the California Supreme Court ignored the sham exception limiting the federal right to petition, and it interpreted the California constitutional right to petition more broadly than reasonably can be justified. Neither approach, lowever, was necessary. Instead, the court could have found that governmental entities, when suing for malicious prosecution, are to be held to a higher standard of proof than that required of nongovernmental plaimtiffs in such actions. ${ }^{94}$ The stricter standard could be analogous to the burden imposed on public figures and public officials in defamation actions. ${ }^{95}$ This increased burden of

91. Cf. CAL. Gov'T CODE \$ 11507.7(i) (West 1980) (explicitly permitting award of court costs and reasonable attorneys' fees for failure to comply with discovery or for seeking to compel discovery without sufficient justification under the Administrative Procedures Act, CAL. Gov'T CODE $\$ \S 11370-11528$ (West 1980 \& Supp. 1983)).

92. Hardy v. Vial, 48 Cal. 2d 577, 581, 311 P.2d 494, 496 (1957) (action for malicious prosecution may be founded upon institution of a proceeding before an administrative agency).

93. See also Note, Groundless Litigation and the Malicious Prosecution Debate: $A$ Historical Analysis, 88 YALE L.J. 1218, 1237 (1979) (suggesting compulsory counterclaim for "groundless suit," but preserving tort of malicious prosecution where compulsory counterclain remedy is unavailable-in wrongful nonjudicial or quasi-judicial proceedings, certain specialized judicial proceedings, and straw-party actious).

94. The Bozek court itself recognized the existence of this higher standard. Having mentioned the standard, lowever, the court failed to further discuss it as an alternative to the finding that the government may never sue for malicious prosecution. See 31 Cal. 3d at 534, 645 P.2d at 140,183 Cal. Rptr. at 90.

95. The standard is found in New York Tines Co. v. Sullivan, 376 U.S. 254 (1964). A pubhic official can only recover for defamation upon showing that the statement was made with " 'actual malice'-that is, with knowledge that it was false or with reckless disregard of whether it was false or not." Id. at 291. The New York Times test permits recovery of punitive damages where actual inalice lras been shown. See Gertz v. Robert Welch, Inc., 418 U.S. 323, 348-49 (1974) (states may not permit recovery of punitive damages absent a showing of knowing falsity or reckless disregard of the truth); Curtis Publishing Co. v. Butts, 388 U.S. 130, 159-61 (1967) (punitive damages permissible on finding sufficient to justify compensatory damages under New York Times). The Supreme Court las not explicitly ruled on whether public figures may recover punitive danages in defamation cases. See Maheu v. Hughes Tool Co., 569 F.2d 459, 478 (9th Cir. 1977) (leaving "open the question of whether [punitive damages] can be awarded in situations in which the high 
proof for governmental entities would lessen the chilling effect the court found so troublesome in Bozek, nainely, that legitimate suits against the government might not be brought if potential plaintiffs feared they might later have to defend against actions for mahicious prosecution.

Currently in California all plaintiffs in malicious prosecution actions inust demonstrate that a prior action initiated by the defendant was terminated in the plaimtiff's favor, that the defendant lacked probable cause to bring the prior action, and that the defendant's primary motivation in bringing suit was some purpose other than the attainment of justice. ${ }^{96}$ It is difficult for a plamtiff in a malicious prosecution action to prove that the defendant lacked probable cause in bringing the prior suit. Ordimarily, the plaintiff may demonstrate lack of probable cause by showing either (1) that the defendant actually believed his prior suit to be groundless, or (2) that no reasonable person would have believed there was any legitimate basis for the suit. ${ }^{97}$

Where the plaintiff in a mahcious prosecution action is a governmental entity, this Note suggests that the plaintiff should have an additional element to demonstrate: that the defendant recklessly disregarded the possibility that his suit was groundless. Government plamtiffs in malicious prosecution suits would thus be required to

and protective standard of actual malice has been met"). Lower courts, however, generally permit such awards on the basis of Gertz. See Maheu, 569 F.2d at 479 (allowing public figure to recover punitive damages and citimg four other courts of appeals that follow same rule); see also Gertz v. Robert Welch, Inc., 680 F.2d 527 (7th Cir. 1982), cert. denied, 103 S. Ct. 1233 (1983) (affirming on remand award of punitive damages upon showing of actual malice).

California generally permits a recovery of punitive damages upon a showing of oppression, fraud, or malice. CAL. CIv. CoDE $\$ 3294$ (West 1970 \& Supp. 1983). Though this Note suggests a burden of proof standard for governmeutal nalicious prosecution plaimtiffs that is analogous to the New York Times test, the interest in protecting the constitutional rights of those who sue the government leads to the conclusion that the government should not be able to recover punitive damages when suing for malicious prosecution. Though "fiagrant abuse of the judicial process is precisely the type of tortious conduct that an award of exemplary damages is designed to deter," Bertero, 13 Cal. 3d at 65, 529 P.2d at 624, 118 Cal. Rptr. at 200, punitive damages would have a severe chilling effect on the constitutional right to sue the government.

This limit on recovery by governmental entities may be of little concern. Though the city of Loug Beach sought punitive damages in its coniplaint, counsel for the city stated at oral argument that the city was seeking only the expenses of defending against Bozek's prior suit. $31 \mathrm{Cal}$. 3d at 531 n.3, 645 P.2d at 139 n.3, 183 Cal. Rptr. at 88 n.3. An award of actual expenses combimed with the inherent deterreuce of permitting governmental entities to sue for inalicious prosecution will adequately protect the interests of the government.

96. See supra text accompanying note 45 .

97. "[P]robable cause requires a reasonable belief in the validity of the claim asserted . . . ." Albertson v. Raboff, 46 Cal. 2d 375, 382, 295 P.2d 405, 410 (1956) (emphasis added). In Bertero the California Supreme Court held that lack of an "actual and honest belief" in the clainn's validity amounted to lack of probable cause, even if a reasonable person might have believed it was meritorious. $13 \mathrm{Cal}$. 3d at 55, 529 P.2d at 617, 118 Cal. Rptr. at 193. Thus, the plaintiff inust actually beheve his claim is valid, and this belief nust be reasonable. 
demonstrate what is currently required plus show that the defendant acted with reckless disregard of the possibility that the suit lacked proper grounds. Reckless disregard, in turn, could be demonstrated by a showing that the defendant believed it likely there was no legitimate ground for filing suit im the prior action. ${ }^{98}$

This proposed standard of proof would place a heavier burden on governmental plaintiffs because proof of the probable cause element would require them to demonstrate the defendant's state of mind. Private malicious prosecution plaintiffs need not slow anything about the defendant's state of mind in proving probable cause if they can demonstrate that no reasonable person would have believed there to have been legitimate grounds for suit. Under the proposed standard, the government would liave to demonstrate that the defendant actually beheved it likely there was no basis for the suit. The distinction between the probable cause reasonableness test and the reckless disregard test is thus the difference between negligence and recklessness. ${ }^{99}$ The effect of imposing this higher standard would be to make the government's case more difficult to demonstrate, thereby deterring the government from instituting actions for inalicious prosecution in all but the clearest of cases. This deterrent, in turn, would reduce the chilling effect upon legitimate suits that could result if the government's right to sue for malicious prosecution was unrestramed. ${ }^{100}$ In addition, the government would still have the option of pursuing malicious prosecution actions, particularly important in situations where the statutory remedies are mapplicable. The higher standard would thus address the concerns expressed in Bozek while protecting the government froin the effects of baseless litigation.

\section{CONCLUSION}

The right to petition for redress of grievances is an important remedy for persons who suffer harm at the hands of governmental entities. Similarly important, however, is the right of governmental entities to be free from baseless lawsuits. Sucl actions are expensive for the gov-

98. "[W]illful misconduct implies the intentional doing of something either with knowledge, express or implied, that serious injury is a probable, as distinguished from a possible, result, or the intentional doing of an act with a wanton and reckless disregard of its consequences. Negligence, of course, is the failure to exercise ordinary care under the circumstances." Williauns v. Carr, 68 Cal. 2d 579, 584, 440 P.2d 505, 509, 68 Cal. Rptr. 305, 309 (1968) (citations omitted).

99. Id.

100. The imposition of a higher standard would thus be preferable to Justice Kaus' suggestion of allowing the statutes to operate concurrently with the traditional malicious prosecution reinedy. $31 \mathrm{Cal} .3$ d at 543, 645 P.2d at 146, $183 \mathrm{Cal}$. Rptr. at 96. An ordinary inalicious prosecution suit by the government, without the higher burden of proof, would not give appropriate weight to the majority's concern with the chilling effect on the right to petition. 
ernment, and ultimately for the taxpayer, and impede access to the courts for those with legitimate grievances. In City of Long Beach $v$. Bozek, the California Supreme Court attempted to strike a balance between these competing concerns by foreclosing all government actions for malicious prosecution. In doing so, it shielded even unwarranted suits from liability for malicious prosecution while allowing governmental entities to recover litigation costs only under alternative statutory provisions.

This Note has argued that the court tipped the balance more lieavily in favor of individual rights than was either necessary or just. In particular, by limiting governmental entities to statutory reinedies, the court precluded all recovery where the government must defend against unfounded claims in administrative or other nonjudicial hearings. Instead of completely foreclosing to governmental entities the common law reinedy of malicious prosecution actions, the court should have imposed a higher standard of proof upon sucl plaintiffs. The imposition of such a standard would serve two purposes. Not only would it preserve an important reinedy to governmental plaintiffs, but at the same time it would lessen the chilling effect upon legitimate claims. Because the government would have a more difficult case to prove, it would be less likely to sue in questionable cases.

Joseph S. Faber*

* B.A. 1981, Johns Hopkins University; third-year student, Boalt Hall School of Law, University of California, Berkeley. 